\title{
MERCURY IN THE SEDIMENT OF PELOTAS RIVER BASIN, BRAZIL
}

\author{
Marcelo B. Remor ${ }^{1 *}$, Silvio C. Sampaio ${ }^{2}$, Kathleen J. Model², Thais D. Falco², \\ Victor H. R. Prudente ${ }^{3}$
}

1*Corresponding author. Universidade Estadual do Oeste do Paraná/ Cascavel - PR, Brasil. Email: remor_@hotmail.com

\section{KEYWORDS}

heavy metal, trace element, multivariate statistics

\begin{abstract}
Many studies have determined the concentration of trace elements in river sediments in Brazil. Notwithstanding, mercury assessments are scarce, especially because of exclusive extraction techniques and expensive analysis techniques. Still, this element is known for its toxicity, persistence, and bioaccumulation, making its presence in the environment an important factor for biota and human health. For this reason, the objective of this study was to determine the mercury concentration in the sediment of the Pelotas River basin, located on the border of the states of Santa Catarina and Rio Grande do Sul. The sediment was collected at eight locations of the Pelotas basin and, after drying, the mercury was quantified by atomic absorption spectrometry based on the Zeeman-background correction, coupled to a pyrolysis reactor. The mercury concentrations in the sediments of the Pelotas River varied from $40.5 \mathrm{ng} \mathrm{g}^{-1}$ to $62.0 \mathrm{ng} \mathrm{g}^{-1}$ and presented a positive correlation with the fraction of silt and clay. The concentrations of mercury found in sediments of the Pelotas River basin have a low probability of negatively affecting the biota. Nonetheless, given the persistence and bioaccumulation potential of this element, the aforementioned region needs further studies to quantify the risks it may cause on the local biota and human health.
\end{abstract}

\section{INTRODUCTION}

During the last few years, research in the field of sedimentology has been focused on sediment production, quantification, and transportation (Sousa et al., 2012; Vanzela et al., 2014; Cerquetani \& Martins Filho, 2006). Additionally, studies have concentrated on the impacts of contaminated sediments on the environment, especially because sediment is considered the main fixator and carrier element in aquatic environments (Pejman et al., 2015; Cembranel et al., 2017a). Among the main contaminants, mercury $(\mathrm{Hg})$ has received special attention because of its high toxicity, environmental persistence, and bioaccumulation potential, which negatively affects humans and environments worldwide (Kim et al., 2016).

Countless human activities contribute to increase $\mathrm{Hg}$ concentrations in the environment, including coalbased thermoelectric plants, incineration of organic products, gold mining, industrial manufacturing processes of organochlorine products, caustic soda, batteries, thermometers, fluorescent light bulbs, and their disposal, along with the production of drugs and fungicides (Kim et al., 2016). As an illustration, when $\mathrm{Hg}$ based pesticides are applied to crops, these areas are considered major sources of $\mathrm{Hg}$ to watercourses and groundwater.

In aquatic environments, microorganisms can transform $\mathrm{Hg}$ into methylmercury $\left(\mathrm{CH}_{3} \mathrm{Hg}\right)$, considered even more toxic than the original element. Consequently, this substance accumulates in the tissue of aquatic animals in higher quantities than those found in the environment. The toxic effect of $\mathrm{Hg}$ on humans and other living organisms depend on factors such as chemical form, environmental concentration, exposure routes, and vulnerability of the exposed organisms (Kim et al., 2016). In humans, elevated concentrations of $\mathrm{Hg}$ can cause neurological, nephrological, immunologic, cardiac, and reproductive disturbances, along with genetic problems and reduction of cognitive functions (Oliveira et al., 2013; Gibb \& O'leary, 2014).

Several studies have already determined the concentrations of trace elements in river sediments in Brazil, notably Melo et al. (2012), Santos et al. (2013), Botero et al. (2014), and Voigt et al. (2016). Nevertheless,

\footnotetext{
${ }^{2}$ Universidade Estadual do Oeste do Paraná/ Cascavel - PR, Brasil.

${ }^{3}$ Instituto Nacional de Pesquisas Espaciais/ São José dos Campos - SP, Brasil.

Received in: 4-7-2017
}

Accepted in: 9-3-2017 
studies involving $\mathrm{Hg}$ are scarce, especially because of the complex technical requirements of exclusive extraction and the high costs of analyses (Franklin et al., 2012). Some of the noteworthy studies are: Siqueira \& Aprile (2012); Hortellani et al., (2013); Almeida et al., (2014); Araujo et al. (2015); Remor et al. (2015); Rocha et al., (2015); and Sahoo et al. (2015).

The Pelotas River basin is a very fragile area, known for its high hydroelectric and industrial potential and intense agricultural activities. Looking to improve the quality of this environment and to prevent its exposure to highly dangerous chemical agents, environmental diagnoses are performed in order to propose management measures and to remediate areas already contaminated or with high contamination risks. Overall, this study aimed to determine the concentrations of $\mathrm{Hg}$ in the sediment of the Pelotas River basin.

\section{MATERIAL AND METHODS}

\section{Study area}

The Pelotas River basin is located on the border of the Brazilian states of Santa Catarina and Rio Grande do Sul (Figure 1). The Pelotas River is the main affluent of the Uruguay River, composing one of the largest basins of Southern Brazil. It possesses a $13,227 \mathrm{~km}^{2}$ drainage area, $62 \%$ in the state of Santa Catarina, and $38 \%$ in the state of Rio Grande do Sul. The climate of the region is considered temperate, with average yearly rainfall of $1623 \mathrm{~mm}$, distributed throughout the year, but having higher concentrations from May to September.

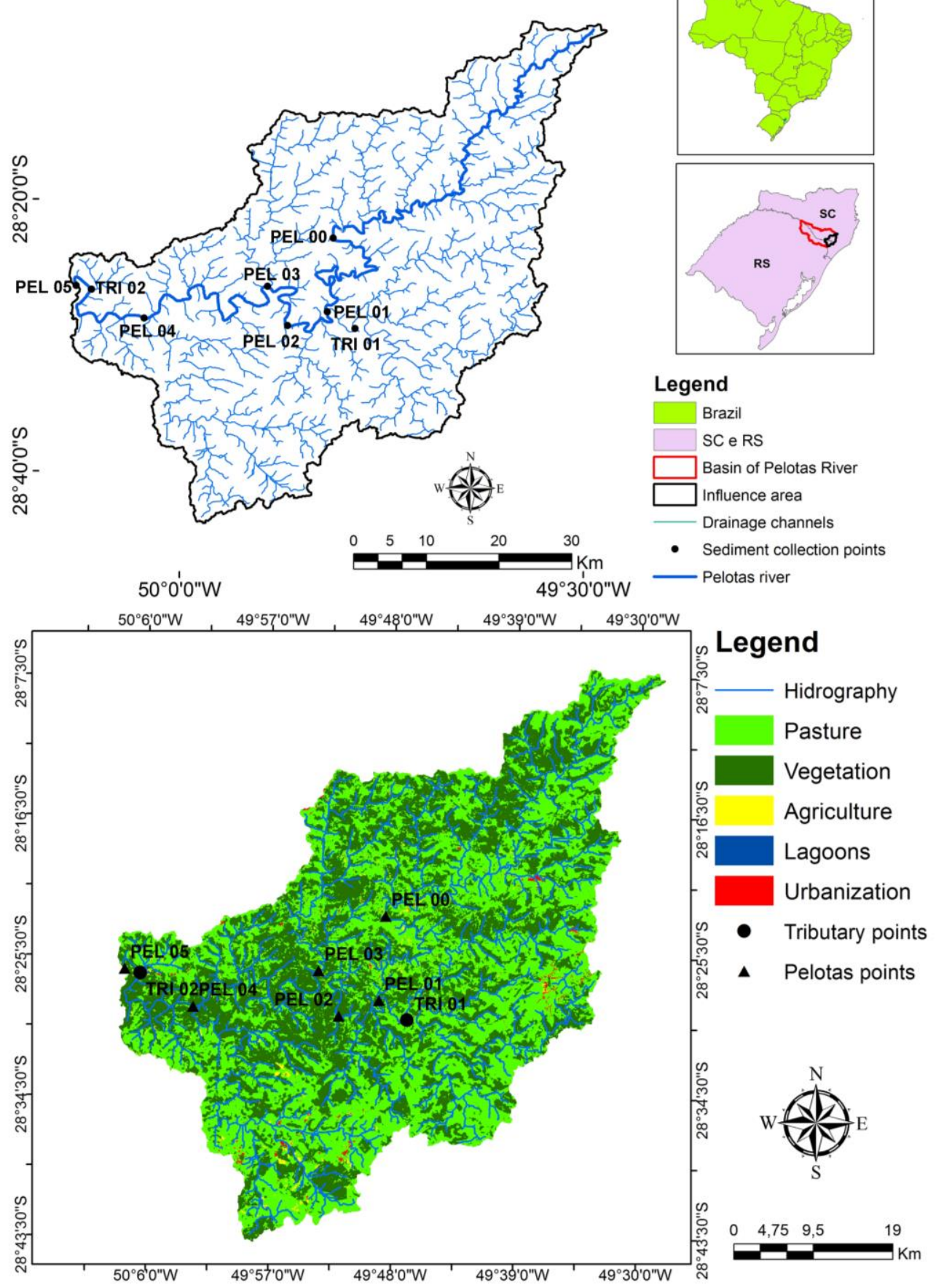

FIGURE 1. Study area geographic location, land use and sediment sampling points within the Pelotas River drainage basin. 
The soil was classified using the Spatial Analysis Tools from the ArcGIS 10 software. Images were used from the Digital Elevation Models, belonging to the TOPODATA project of the Brazilian National Institute for Spatial Research (INEP). The use of soil used in areas of influence was classified by using images from an orbital sensor taken on January 30,2014 , by the Landsat 8 satellite. The classification was done in a supervised manner, using the Maximum Likelihood algorithm from the SCP (Semi-Automatic Classification Plugin) plugin of the open source QGIS software, version 2.14.5. Figure 1 illustrates the soil use classes, wherein pastures occupy $52.79 \%$ of the total area of influence, followed by vegetation $(45.16 \%)$, agriculture $(0.92 \%)$, and urban area $(0.46 \%)$. Furthermore, the basin houses industrial activities such as timber, pulp \& paper, construction, and agriculture. The hydroelectric potential becomes apparent due to the extremely wavy relief and the presence of the Machadinho and Barra Grande hydroelectric power plants (HPP), as well as the possibility of installing the Pai Querê and three other HPPs, which are under licensing process now.

\section{Sample collection and preparation}

Sediment samples were collected from eight sites within the Pelotas River basin, using a Petersen sampler. Six locations in the Pelotas River (PEL 00, PEL 01, PEL 02, PEL 03, PEL 04, PEL 05) and two in its tributaries (TRI 01 - Contas River and TRI 02 -São Sebastião do Arvoredo Stream) (Figure 1). Five samples were collected from each location, constituting a composite sample by the norms of ANA (National Water Agency). Sampling was carried out in February 2014, a period with the lowest annual rainfall average. This is important because the fine river sediments are deposited during the dry season, and are washed away during the rainy season. Thus, only one yearly sampling during the dry season is sufficient for analysis (ANA, 2011). After collecting the samples, they were transported in a refrigerated vehicle $\left(4^{\circ} \mathrm{C}\right)$ and later dried out in an enclosed area, away from the sun and at room temperature.

\section{Physicochemical analyses}

Particle size analyses were conducted with a combination of sedimentation and sieving procedures, according to the NBR 7181/1984 standard of the Brazilian Association of Technical Norms (ABNT). The total organic carbon (TOC) was determined by the modified Walkley-Black method (Coser et al., 2012).

The chemical elements were only quantified in the silt + clay fraction $(<63 \mu \mathrm{m})$, as recommended by the World Health Organization (WHO, 1982). In order to do so, after drying, the sediment samples were sieved through a PVC and nylon sieve with a $63 \mu \mathrm{m}$ mesh net.

The elements aluminum (Al), iron (Fe), and manganese $(\mathrm{Mn})$ were extracted on a wet basis, using the 3050B method of USEPA (UNITED STATES ENVIRONMENTAL PROTECTION AGENCY). This extraction method was developed to quantify the fractions of metals that could become environmentally available.
After extraction, these elements were quantified by flame atomic absorption spectrometry (FAAS). Data accuracy was evaluated by the analytical methods for IAEA 356 and IAEA 433 certifications as reference materials (marine sediment), which were in line with the results at the $95 \%$ confidence level.

Total mercury $(\mathrm{Hg})$ was quantified by atomic absorption spectrometry based on Zeemanbackground correction, with a pyrolysis reactor. First, the solid sample (sediment) is thermally disrupted, and then the $\mathrm{Hg}$ vapor is measured (Castilhos et al., 2006; Fiori et al., 2013). The accuracy of these data was evaluated by comparing it to Mess-3 sample (marine sediment), i.e. certified reference material, checking the consistency of at least $95 \%$.

\section{Data analysis}

Sediment particle-size analyses were interpreted through the ternary diagrams of Shepard (1954) and Pejrup (1988) to determine texture and hydrodynamics, respectively. These interpretations were performed in the $\mathrm{R}$ environment using the RYSGRAN package (Gilbert et al., 2012).

The set of sediment physicochemical variables was summarized in a Principal Component Analysis (PCA) by the PCORD 5.0 software. This assessment reduces the set of original variables into a set of Principal Components (PC), looking to maintain the maximum variability of the original set. PCA was performed on the Pearson correlation matrix of variables, adopting the broken-stick retention criterion, i.e. with eigenvalues higher than those randomly expected (Jackson, 1993). To interpret the meaning of retained PCs of original variables, only Pearson correlation coefficients higher than $70 \%$ were considered (Jolliffe, 1986).

\section{RESULTS AND DISCUSSION}

Particle size analysis was used to classify the sediment samples by texture and hydrodynamics (Figure 2). The Shepard Diagram (Figure 2A), on the other hand, displays the texture variability among locations. The PEL 02 site showed a silty clay texture, while PEL 01 and PEL 04 had sandy silty clay textures and PEL 00 a silty clayey sand texture. Both TRI 01 and PEL 03 sites had a clayey sandy textures while TRI 02 revealed a sandy clayey silt texture and PEL 05 a silty sand texture.

The hydrodynamics in PEL 00, PEL 03, PEL 05, and TRI 02 was high according to the Pejrup diagram (Figure 2B). On the other hand, PEL 01, PEL 02, PEL 04, and TRI 01 presented moderate hydrodynamics. The sites with elevated hydrodynamics had higher proportions of sand, from about $52 \%$ to $72 \%$. In high hydrodynamicenergy environments, fine particles remain suspended and then transported to environments with lower energy levels, where they are sedimented (Noronha-D'mello \& Nayak, 2015). 

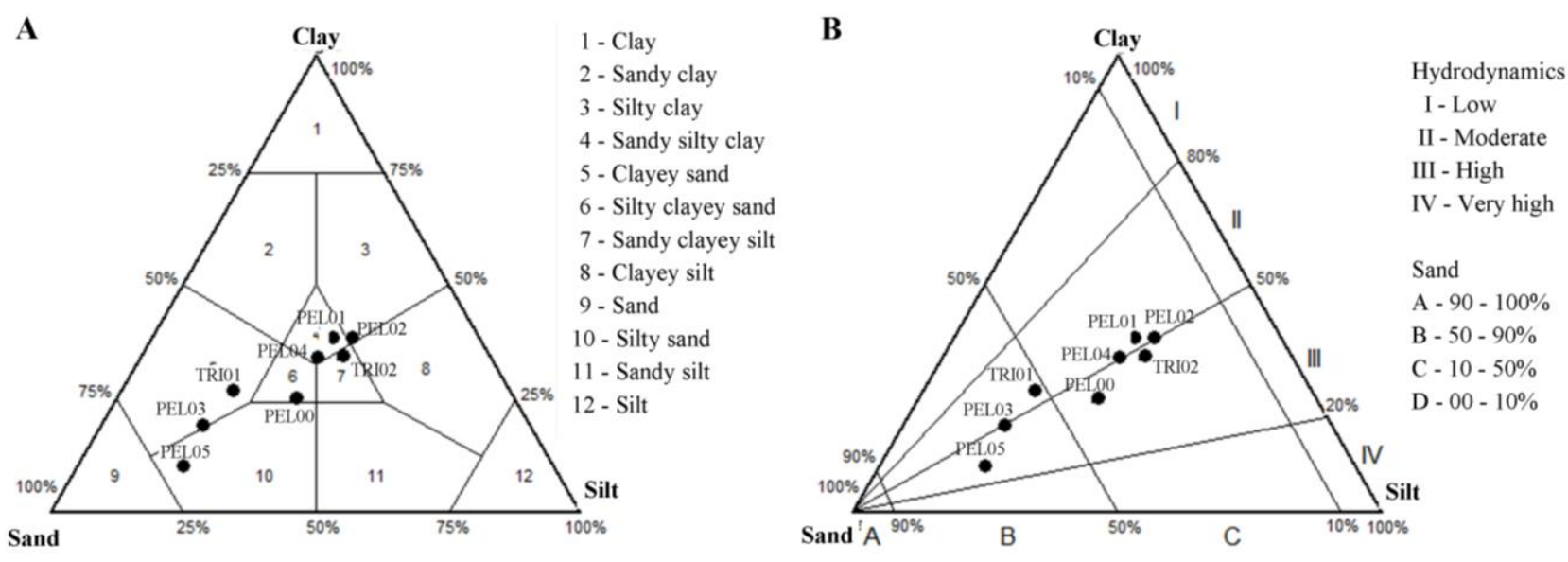

FIGURE 2. Textural composition and hydrodynamics of the bottom sediments of the Pelotas River. A: Shepard Diagram. B: Pejrup Diagram.

Figure 3 exhibits the PCA for the set of physicochemical variables of sediments. According to the broken-stick criterion, two PCs were considered for the analysis; they comprised $69.22 \%$ of the total variability. In the positive quadrant, the PC 1 is composed of the variables sand, Al, and gravel; yet, in the negative one, it is composed of the variables clay, silt, and $\mathrm{Hg}$ (Figure 3). The PC 2 in the negative quadrant is composed of the variables $\mathrm{Mn}$ and $\mathrm{Fe}$. Conversely, TOC was taken as uninterpretable by the broken-stick criterion, thus presenting lower variability among the locations than the random variability (Jackson, 1993). Therefore, no significant statistical difference among the sampled locations was registered. The PC 1 separated the sites into three groups: the first, formed by PEL 03 and PEL 05, which had the highest results for sand, Al, and gravel; the second, by PEL 02, TRI 02, and PEL 01, where the highest levels of clay, silt, and $\mathrm{Hg}$ were found; and the third, by PEL 00, TRI 01, and PEL 04, with intermediate values for the variables included in PC 1 (Figure 3). PC 02 separated PEL 02 from the rest of sites since it had the highest levels of $\mathrm{Mn}$ and $\mathrm{Fe}$, and the lowest concentrations of the variables forming PC 02 (Figure 3).

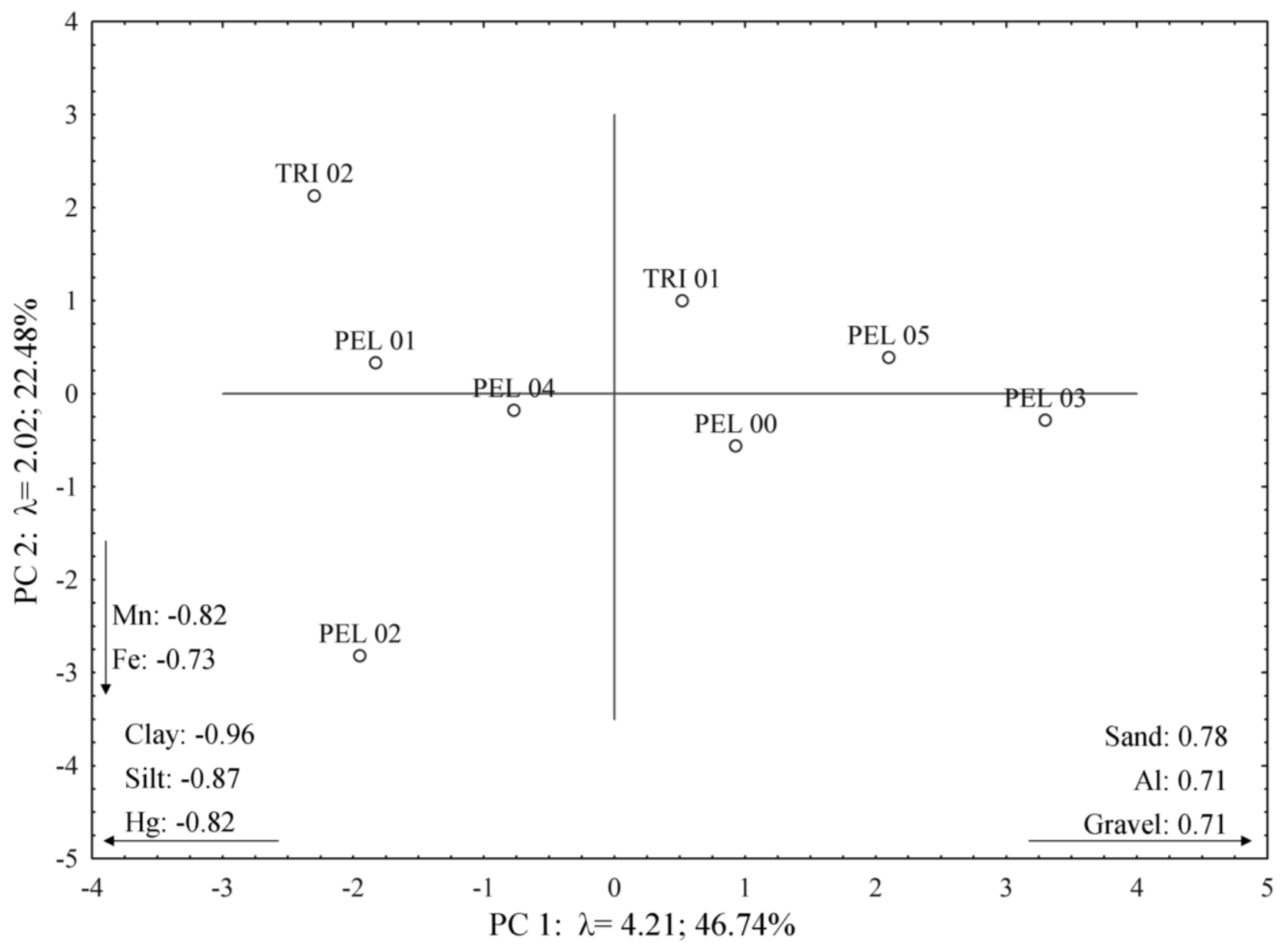

FIGURE 3. Principal Component Analysis (PCA) of the physicochemical variables of sediments from the Pelotas River. 
The positive correlation between the finer portion of sediments (silt and clay) and $\mathrm{Hg}$ contents (Figure 3 ) is due to the larger surface area of fine particles, increasing their adsorption capacity (Oliveira et al., 2011; Cembranel et al., 2017b). Thus, clay is considered an important factor for $\mathrm{Hg}$ adsorption in soils and sediments (Araujo et al., 2015). The PCA shows the lack of correlation between $\mathrm{Hg}$ and the contents of $\mathrm{TOC}, \mathrm{Al}, \mathrm{Fe}$, and $\mathrm{Mn}$. In this experiment, only the fractions of elements environmentally available were quantified, confirming the association between most of the $\mathrm{Hg}$ found and the fine portion of sediments (silt and clay). This result points out the complexing minerals as absorbent agents for $\mathrm{Hg}$, albeit they are commonly unavailable for reactions with the aquatic environment, i.e. there is a low probability of it being incorporated by the aquatic biota (Araujo et al., 2015).

By observing the PCA results, it seems that the largest fraction of $\mathrm{Hg}$ found in sediments is in its least reactive form (adsorbed to complexing minerals), which is hardly available to the ecosystem. Elements of anthropogenic origins are predominantly found in sediment parts that are more unstable, which are vulnerable to small environmental changes (Bartoli et al., 2012). Hence, we believe the largest fraction of $\mathrm{Hg}$ in sediments from the Pelotas River is most likely of geogenic origin. However, thorough studies in this region are still necessary to confirm these results.

Figure 4 shows the $\mathrm{Hg}$ concentrations in the sediment of the Pelotas River. The locations presenting higher concentrations (PEL 01, PEL 02, PEL 04, and TRI 02) were the same that had higher quantities of fine sediments (silt and clay) and moderate hydrodynamics (Figure 2). This supports the results obtained in the PCA (Figure 3), which showed a correlation of $\mathrm{Hg}$ concentrations with silt and clay fractions.

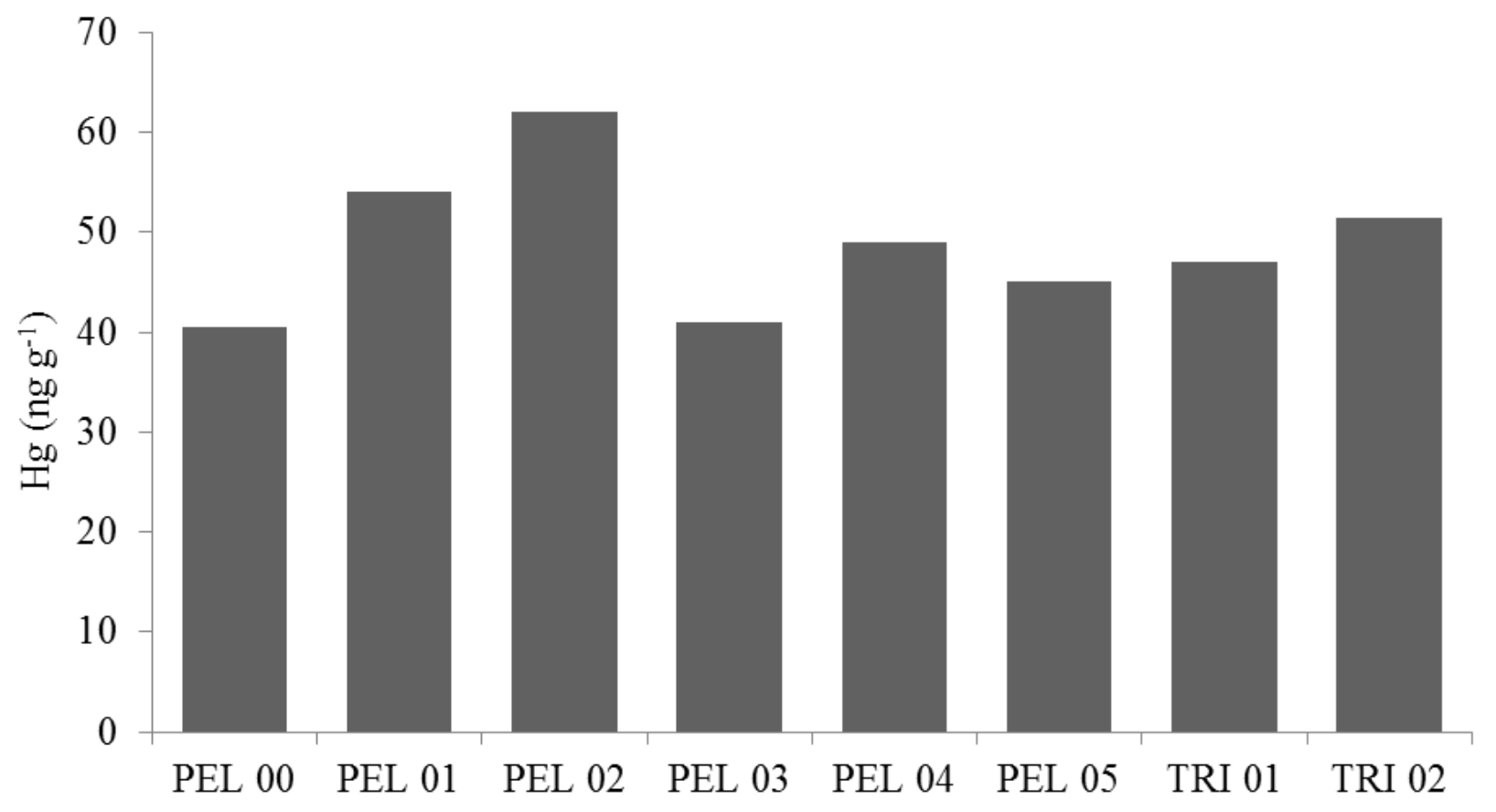

FIGURE 4. Mercury concentrations in the bottom sediments of the Pelotas River.

The $\mathrm{Hg}$ concentrations in the bottom sediments of the Pelotas River varied from $40.5 \mathrm{ng} \mathrm{g}^{-1}$ to $62.0 \mathrm{ng} \mathrm{g}^{-1}$ (Figure 4; Table 1). Our findings were compared to those of other studies in Brazilian river environments, as shown Table 1. In general, the highest levels of $\mathrm{Hg}$ found in this research were lower than were those reported by other authors. Furthermore, according to the CONAMA resolution $n^{\circ} 454 / 2012$ (Brazilian National Environmental Committee), $\mathrm{Hg}$ concentrations lower than $170 \mathrm{ng} \mathrm{g}^{-1}$ (level 1) have smaller probabilities of adversely affecting the biota, and only those above $486 \mathrm{ng} \mathrm{g}^{-1}$ (level 2) could. Therefore, the concentrations found in the Pelotas River show a low probability of risk to the biota. Nevertheless, Castro et al., (2016) demonstrated the bioaccumulation potential of $\mathrm{Hg}$ when studying the Purus River. These researchers found $\mathrm{Hg}$ concentrations between 38 and $65 \mathrm{ng} \mathrm{g}^{-1}$ in the sediment of the Purus River, while in carnivorous fish muscle, it reached up to $5384 \mathrm{ng} \mathrm{g}^{-1}$, with an average of $927 \mathrm{ng} \mathrm{g}^{-1}$. This outcome demonstrates the high toxicity, persistence, and bioaccumulation potential of this element. In this context, it is important to emphasize the need for further studies to quantify the risks to aquatic biota and human health in the Pelotas River basin. 
TABLE 1. Mercury concentration in sediments of river environments in Brazil.

\begin{tabular}{|c|c|c|c|c|c|c|c|}
\hline \multirow{2}{*}{ Location } & \multicolumn{2}{|c|}{ Coordinates } & \multicolumn{3}{|c|}{$\mathrm{Hg}\left(\mathrm{ng} \mathrm{g}^{-1}\right)$} & \multirow{2}{*}{ Impact } & \multirow{2}{*}{ Reference } \\
\hline & Latitude & Longitude & Min & Aver & Max & & \\
\hline Pelotas River * & $29^{\circ} 29^{\prime} 36^{\prime \prime S}$ & $50^{\circ} 07^{\prime} 38^{\prime \prime} \mathrm{W}$ & 40.5 & 48.7 & 62.0 & & This study \\
\hline Teles Pires River & $09^{\circ} 25^{\prime} 19^{\prime \prime} \mathrm{S}$ & $56^{\circ} 32^{\prime} 20^{\prime \prime} \mathrm{W}$ & $90 ., 0$ & 148.0 & 250.0 & $\mathrm{M} ; \mathrm{A}$ & Wasserman et al., 2007 \\
\hline Paranaita River & $09^{\circ} 28^{\prime} 09^{\prime \prime S}$ & $56^{\circ} 41^{\prime} 45^{\prime \prime} \mathrm{W}$ & 50.0 & 83.6 & 140.0 & $\mathrm{M} ; \mathrm{A}$ & Wasserman et al., 2007 \\
\hline Botafogo River & $07^{\circ} 42^{\prime} 51^{\prime \prime S}$ & $34^{\circ} 52^{\prime} 53^{\prime \prime} \mathrm{W}$ & 1.0 & 138.7 & 250.0 & I & Lima et al., 2009 \\
\hline Paraíba do Sul River & $21^{\circ} 40^{\prime} 00^{\prime \prime} \mathrm{S}$ & $41^{\circ} 10^{\prime} 00^{\prime \prime} \mathrm{W}$ & 22.2 & 56.1 & 158.3 & $\mathrm{M} ; \mathrm{FO}$ & Araujo et al., 2015 \\
\hline Ivinhema River & $22^{\circ} 49^{\prime} 31^{\prime \prime S}$ & $53^{\circ} 33^{\prime} 12^{\prime \prime} \mathrm{W}$ & 25.0 & 78.0 & 125.0 & $\mathrm{M} ; \mathrm{A}$ & Remor et al., 2015 \\
\hline Paraná River & $22^{\circ} 43^{\prime} 31^{\prime \prime S}$ & $53^{\circ} 18^{\prime} 15^{\prime \prime} \mathrm{W}$ & 36.0 & 55.0 & 67.0 & NR & Remor et al., 2015 \\
\hline Violão Lake & $06^{\circ} 24^{\prime} 00^{\prime \prime S}$ & $50^{\circ} 21^{\prime} 10^{\prime \prime} \mathrm{W}$ & 130.0 & 240.0 & 590.0 & NR & Sahoo et al., 2015 \\
\hline Purus River & $08^{\circ} 52^{\prime} 50^{\prime \prime} \mathrm{S}$ & $69^{\circ} 13^{\prime} 10^{\prime \prime} \mathrm{W}$ & 38.0 & 50.0 & 65.0 & NR & Castro et al., 2016 \\
\hline
\end{tabular}

*This study; Impact: human activities conducted in the drainage basins correlated to the increase of $\mathrm{Hg}$ concentration in the sediments of their respective rivers, as cited by the authors. M: gold mining; GO: organomercurial fungicides; A: Agriculture; I: Industrial production of chloride and soda; NR: non-reported group.

\section{CONCLUSIONS}

This study found no correlation between human activities and mercury concentrations in the sediment of the Pelotas River basin and its tributaries. The mercury concentrations found in the sediment have little chance of causing adverse effects on local biota. Yet, the high toxicity, persistence, and bioaccumulation potential of mercury emphasizes the need for further investigations in this region with the purpose of quantifying risks it may cause to aquatic biota and human health.

\section{ACKNOWLEDGEMENTS}

The authors would like to thank the financial aid provided by the CNPq (Brazilian Committee for Scientific and Technological Development), CAPES (Coordination for the Improvement of Higher Education Personnel), UNIOESTE (Western Paraná State University), and PGEAGRI (Post-graduation Program in Agricultural Engineering).

\section{REFERENCES}

Almeida R, Bernardi JVE, Oliveira RC, Carvalho DP, Manzatto AG, Lacerda LD. Bastos WR (2014) Flood pulse and spatial dynamics of mercury in sediments in Puruzinho lake, Brazilian Amazon. Acta Amazonica 44:99-105. DOI: http://dx.doi.org/10.1590/S0044-59672014000100010

ANA - Agência Nacional De Águas (2011) Guia nacional de coleta e preservação de amostras: água, sedimento, comunidades aquáticas e efluentes líquidos. ANA, 326p.

Araujo BF, Almeida MG, Rangel TP, Rezende CE (2015) Distribuição e fracionamento do hg em sedimentos do rio Paraíba do Sul - RJ, Brasil. Química Nova 38:30-36. DOI: http://dx.doi.org/10.5935/0100-4042.20140268

Bartoli G, Papa S, Sagnella E, Fioretto A (2012) Heavy metal content in sediments along the Calore river: relationships with physical-chemical characteristics. Journal of Environmental Management 95:S9-14. DOI: http://dx.doi.org/10.1016/j.jenvman.2011.02.013

Botero WG, Souza SO, Santos OS, Oliveira LC (2014) Influência das substâncias húmicas de sedimentos na biodisponibilidade de metais para o sistema aquático. Química. Nova 37:943-949. DOI:

http://dx.doi.org/10.5935/0100-4042.20140164
Castilhos ZC, Rodrigues S, Rodrigues APC, Villas-Boas RC, Siegel S, Veiga MM, Beinhoff C (2006) Mercury Contamination in Fish from Gold Mining Areas in Indonesia and Human Health Risk Assessment. Science of the Total Environment 368:320-325. DOI: http://dx.doi.org/10.1016/j.scitotenv.2006.01.039

Castro NSS, Braga CM, Trindade PAA, Giarrizzo T, Lima MO (2016) Mercury in fish and sediment of Purus River, Acre State, Amazon. Cadernos Saúde Coletiva 24:294300. DOI: http://dx.doi.org/10.1590/1414$462 \times 201600030142$

Cembranel AS, Frigo EP, Sampaio SC, Mercante E, Reis RRDos, Remor MB. (2017a). Residue analysis of organochlorine and organophosphorus pesticides in urban lake sediments. Engenharia Agrícola, 37(6), 1254-1267. doi: 10.1590/1809-4430-eng.agric.v37n6p1254-1267/2017

Cembranel AS, Sampaio SC, Remor MB, Gotardo JT, Rosa PMD (2017b). Geochemical Background in an Oxisol. Engenharia Agrícola 37(3):565-573. DOI: http://dx.doi.org/10.1590/1809-4430eng.agric.v37n3p565-573/2017

Cerquetani GE, Martins Filho MV (2006) Rotina computacional e equação simplificada para modelar o transporte de sedimentos num Latossolo Vermelho Distrófico. Engenharia Agrícola 26:617-626. DOI: http://dx.doi.org/10.1590/S0100-69162006000200032

Coser TR, De Figueiredo CC, Ramos MLG, Jannuzzi H, Marchão RL (2012). Recuperação de carbono obtida por três métodos em frações da matéria orgânica de Latossolo sob consórcio milho forrageiras, no Cerrado. Bioscience Journal 28:91-97.

Fiori CS, Rodrigues APC, Santelli RE, Cordeiro RC, Carvalheira RG, Araújo PC, Castilhos ZC, Bidone ED (2013) Ecological risk index for aquatic pollution control: a case study of coastal water bodies from the Rio de Janeiro State, southeastern Brazil. Geochimica Brasiliensis 27:24-36.

Franklin RL, Bevilacqua JE, Favaro DIT (2012) Organic and total mercury determination in sediments by cold vapor atomic absorption spectrometry: methodology validation and uncertainty measurements. Química Nova 35:45-50. DOI: http://dx.doi.org/10.1590/S010040422012000100009 
Gibb H, O'leary KG (2014) Mercury exposure and health impacts among individuals in the artisanal and small-scale gold mining community: A comprehensive review. Environmental Health Perspectives 122:667-672. DOI: http://dx.doi.org/10.1289/ehp.1307864

Gilbert ER, Camargo MG, Sandrini-Neto L (2012) Rysgran; Grain size analysis, textural classifications and distribution of unconsolidated sediments; R package version 2.0.

Hortellani MA, Sarkis JES, Menezes LCB, BazanteYamaguishi R, Pereira ASA, Garcia PFG, Maruyama LS, Castro PMG (2013) Assessment of metal concentration in the Billings Reservoir sediments, São Paulo State, Southeastern Brazil. Journal of the Brazilian Chemical Society 24:58-67. DOI: http://dx.doi.org/10.1590/S010350532013000100009

Jackson DA (1993) Stopping Rules in Principal Components Analysis: A Comparison of Heuristical and Statistical Approaches. Ecology 74:2204-2214. DOI: http://dx.doi.org/10.2307/1939574.

Jolliffe IT (1986) Principal component analysis New York, Springer. $487 \mathrm{p}$.

Kim K, Kabir E, Jahan SA (2016) A review on the distribution of $\mathrm{Hg}$ in the environment and its human health impacts. Journal of Hazardous Materials 306:376-385. DOI: http://dx.doi.org/10.1016/j.jhazmat.2015.11.031

Lima ACG, Motta M, Silva VL, Silva MCL, Ferreira JM (2009) Monitoramento da qualidade e avaliação contaminação por mercúrio na água e sedimentos do rio Botafogo, PE, Brasil. Ambiente \& Água 4:156-171. DOI: http://dx.doi.org/10.4136/ambi-agua.95

Melo VF, Andrade M, Batista AH, Favaretto N, Grassi MT, Campos MS (2012) Chumbo e zinco em águas e sedimentos de área de mineração e metalurgia de metais. Química Nova 35:22-29. DOI: http://dx.doi.org/10.1590/S0100-40422012000100005

Noronha-D'mello CA, Nayak GN (2015) Geochemical characterization of mangrove sediments of the Zuari estuarine system, West coast of India. Estuarine, Coastal and Shelf Science 167:313-325. DOI: http://dx.doi.org/10.1016/j.ecss.2015.09.011

Oliveira GA, Rocha GC, Macedo JAB, Britto MC (2013) Percepção de risco à contaminação por mercúrio em uma antiga área de garimpo de ouro em descoberto/MG. Revista de geografia 2(2):1-6.

Oliveira LC, Botero WG, Santos A, Cordovil MCO, Rocha JC, Silva HC (2011) Influência das características físicoquímicas dos solos no ciclo hidrobiogeoquímico do mercúrio na região do Rio Aracá - AM. Química Nova 34:1303-1308. DOI: http://dx.doi.org/10.1590/S010040422011000800002

Pejman A, Bidhendi GN, Ardestani M, Saeedi M, Baghvand A (2015) A new index for assessing heavy metals contamination in sediments: A case study. Ecological indicators 58:365-373. DOI: http://dx.doi.org/10.1016/j.ecolind.2015.06.012
Remor MB, Sampaio SC, Damatto SR, Castilhos ZC, Stevaux JC, Vilas Boas MA, dos Reis RR (2015) Geochemistry of the Upper Paraná River floodplain: study of the Garças Pond and Patos Pond. Journal of Radioanalytical and Nuclear Chemistry 305:409-418. DOI: http://dx.doi.org/10.1007/s10967-015-4021-9

Rocha ARM, di Beneditto APM, Pestana IA, Souza CMM (2015) Isotopic profile and mercury concentration in fish of the lower portion of the rio Paraíba do Sul watershed, southeastern Brazil. Neotropical Ichthyology 13:723-732. DOI: http://dx.doi.org/10.1590/1982-0224-20150047

Sahoo PK, Souza-Filho PWM, Guimarães JTF, Silva MS, Costa FR, Manes CLO, Oti D, Silva Júnior RO, Dall'agnol $\mathrm{R}$ (2015) Use of multi-proxy approaches to determine the origin and depositional processes in modern lacustrine sediments: Carajás Plateau, theasternAmazon, Brazil. Applied Geochemistry 52:130-146. DOI: http://dx.doi.org/10.1016/j.apgeochem.2014.11.010

Santos JS, Souza FM, Santos MLP (2013) Distribuição de $\mathrm{Zn}, \mathrm{Pb}, \mathrm{Ni}, \mathrm{Cu}, \mathrm{Mn}$ e Fe nas frações do sedimento superficial do rio Cachoeira na região sul da Bahia, Brasil. Química Nova 36:230-236. DOI:

http://dx.doi.org/10.1590/S0100-40422013000200005

Siqueira GW, Aprile FM (2012) Distribuição de mercúrio total em sedimentos da plataforma continental Amazônica: Brasil. Acta Amazonica 42:259-268. DOI: http://dx.doi.org/10.1590/S0044-59672012000200012

Sousa GB, Martins Filho MV, Matias SSR (2012) Perdas de solo, matéria orgânica e nutrientes por erosão hídrica em uma vertente coberta com diferentes quantidades de palha de cana-de-açúcar em Guariba - SP. Engenharia Agrícola 32(3):490-500. DOI:

http://dx.doi.org/10.1590/S0100-69162012000300008

Vanzela LS, Grecco DLG, Costa Neto JN, Santos GO (2014) Evaluation of sediment production and siltation in a small earth dam in Fernandópolis, SP. Engenharia Agrícola 34(5):912-924. DOI: http://dx.doi.org/10.1590/S0100-69162014000500010

Voigt CL, Silva CP, Campos SX (2016) Avaliação da bioacumulação de metais em Cyprinus carpio pela interação com sedimento e água de reservatório. Química Nova 39:180-188. DOI: http://dx.doi.org/10.5935/01004042.20160014

Wasserman JC, Campos RC, Hacon SS, Farias RA, Caires SM (2007) Mercury in soils and sediments from gold mining liabilities in southern Amazônia. Química Nova 30:768-773. DOI: http://dx.doi.org/10.1590/S010040422007000400003

WHO - World Health Organization (1982)

Micropollutants in river sediments. WHO, 85p. 